\title{
THE USE OF MANGROVE STANDS FOR SHRIMP POND WASTE-WATER TREATMENT
}

\author{
Taufik Ahmad"), Mohammad Tjaronge"), and Fuad Cholik")
}

\begin{abstract}
Degraded coastal environmental quality due to mangrove forest conversion is strongly suspected as a cause of the decline of shrimp pond productivity in Indonesia. In addition, the heavy inputs in shrimp culture practices have excessively polluted and enriched the coastal water, which in turn stimulates the growth of pathogenic bacteria. In an effort to prevent further negative effects of shrimp culture practices, experiments were carried out to assess the capability of mangrove stands to reduce pollutants (nitrate, phosphate, total organic matter, and total bacteria) contained in shrimp pond waste-water. Three pond sizes, i.e, $5 \times 5,10 \times 10$, and $15 \times 15 \mathrm{~m}^{2}$, three replicates each, planted with Rhizophora mucronata were used as waste-water treatment ponds. The shrimps (PL-45) were stocked into seven ponds of $500 \mathrm{~m}^{2}$ each, at a density of $20 \mathrm{shrimp} / \mathrm{m}^{2}$. Feed was given 3 times with the total amount $10-3 \%$ of shrimp biomass per day. Water changes in shrimp ponds were carried out every three days, with $30 \%$ of the waste-water channeled into mangrove ponds and held for another three days. The waste-water was replaced with reservoir water. The water and soil in both shrimp and mangrove ponds as well as in control pond, were sampled every three days prior to water exchange. The $\mathrm{NO}_{3}-\mathrm{N}, \mathrm{PO}_{4}-\mathrm{P}, \mathrm{TOM}$ concentrations and total bacteria populations were not different among mangrove ponds sizes. $\mathrm{NO}_{3}-\mathrm{N}$ tended to precipitate, while most of the $\mathrm{PO}_{4}-\mathrm{P}$ tended to dissolve in water. Total organic matter (TOM) in mangrove ponds and soil fluctuated at a similar level and pattern with that in shrimp ponds. The population of bacteria in both water and soil of mangrove ponds was slightly lower, even though statistically not significant, than that in shrimp ponds. Thus mangrove stands may have potential for reducing the negative effects of waste-water from shrimp ponds on the environment.
\end{abstract}

KEYWORDS: mangrove, shrimp pond, waste water treatment

\section{INTRODUCTION}

Starting from 1980 shrimp culture has developed at a rapid pace, which has brought about a significant increase in cultured shrimp production. Unfortunately, the increase in production was accompanied by distinct conversion of mangrove forest into shrimp ponds. Excessive inputs in shrimp culture and extinction of mangroves in the area in turn enhance the growth of pathogenic bacteria which leads to shrimp harvest failure. Since 1994, cultured shrimp production has been decreasing every year and in 1999 the production was less than three-quarters of the production in 1992.

Although the ability of mangroves to neutralize pollutants is not proven, based on their abilities to absorb and use nutrients resulting from decomposing organic wastes for growth (Massaut, 1998), it is probable that mangroves could settle and neutralize wastewater, especially organic wastes (Soemodiharjo and Soeroyo, 1992). The mangrove root system which is commonly dense is able to retain pollutant particles and develop sedimentation (Kartawinata et al., 1978) as well as to allow organic matter decomposition (Boyd, 1999). The pores or lenticell in stilt roots, especially in Rhizophora spp., function to exchange gas allowing the mangrove to grow both in anaerobic and aerobic conditions (Notohadiprawiro, 1978; Nontji, 1984; Soemodiharjo \& Soeroyo, 1994).

Atmawidjaja (1987) observed the effect of municipal sewage on a mangrove community and concluded that the mangrove community is not harmed ivy municipal sewage and to some extent could be used as an organic waste dumping site. In addition, oysters (Crassostrea rhizophora) attached on mangrove roots and mangrove cockles (Geloina coaxan) dwelling in the mangrove ecosystem are excellent biofilters for shrimp ponds (Suharyanto et al., 1996; Mangampa et al., 1998; Tjaronge et al., 1998)

Based on those potentialities, this study aimed at assessing the capability of mangrove stands, dominated by Rhizophora mucronata, to neutralize shrimp ponds waste-water. Knowledge about the capability of mangrove stands to neutralize such waste could

Researcher at the Research Center of Aquaculture

") Researcher at the Research Institute for Coastal Fisheries, Maros 
help in the designing an eco-friendly or responsible coastal aquaculture.

\section{MATERIALS AND METHODS}

Two-year old mangrove stands, mostly Rhizophora mucronata, were separated into the only three pond sizes available, i.e. $5 \times 5,10 \times 10$, and $15 \times 15 \mathrm{~m}^{2}$, the sizes available with 3 replicates each and $1.0 \mathrm{~m}$ high dykes. The density of mangrove in each pond was not different, nine trees $/ \mathrm{m}^{2}$. Two ponds with no mangroves were used as settlement ponds or controls. Each pond was filled with the water flowing from the shrimp ponds; the water was held for three days prior to sampling and then channeled out into the environment. The water and the bottom soil of the ponds were sampled in each pond every 15 days. The soil samples for each pond were pooled from five different samples collected using a soil auger until $10 \mathrm{~cm}$ depth. The variables observed were $\mathrm{NO}_{3}-\mathrm{N}, \mathrm{PO}_{4}-\mathrm{P}$, total organic matter (TOM) concentrations, and the bacterial population as well as benthos and plankton. The benthos were sampled using an Eikman's dredge, at five stations in each pond, and a sieve was used to separate the molluscs from debris and other organisms. The plankton was sampled using a plankton net no. 25 to filter $100 \mathrm{~L}$ water from each ponds. The data of $\mathrm{NO}_{3}-\mathrm{N}, \mathrm{PO}_{4}-\mathrm{P}$, and TOM concentrations as well as total bacteria population of each pond were descriptively analysed. The data of each pond were computed to obtain the average data for mangrove ponds.

The shrimp ponds consisted of seven compartments (Figure 1), $500 \mathrm{~m}^{2}$ each, and were stocked with $20 \mathrm{PL}-45 / \mathrm{m}^{2}$. The water in the ponds was maintained at $90-100 \mathrm{~cm}$ depth. A 1-kwh paddlewheel aerator was set in each pond. The feed was given at $10 \%$ total biomass per day in the first month and reduced to $5 \%$ in the second month and 3\% total biomass in the third month. The amount of feed given was adjusted based on the estimation on total biomass every 15 days. The water was changed every three days by allowing $30 \%$ of the total volume to flow out into the mangrove ponds with replacement from a reservoir.

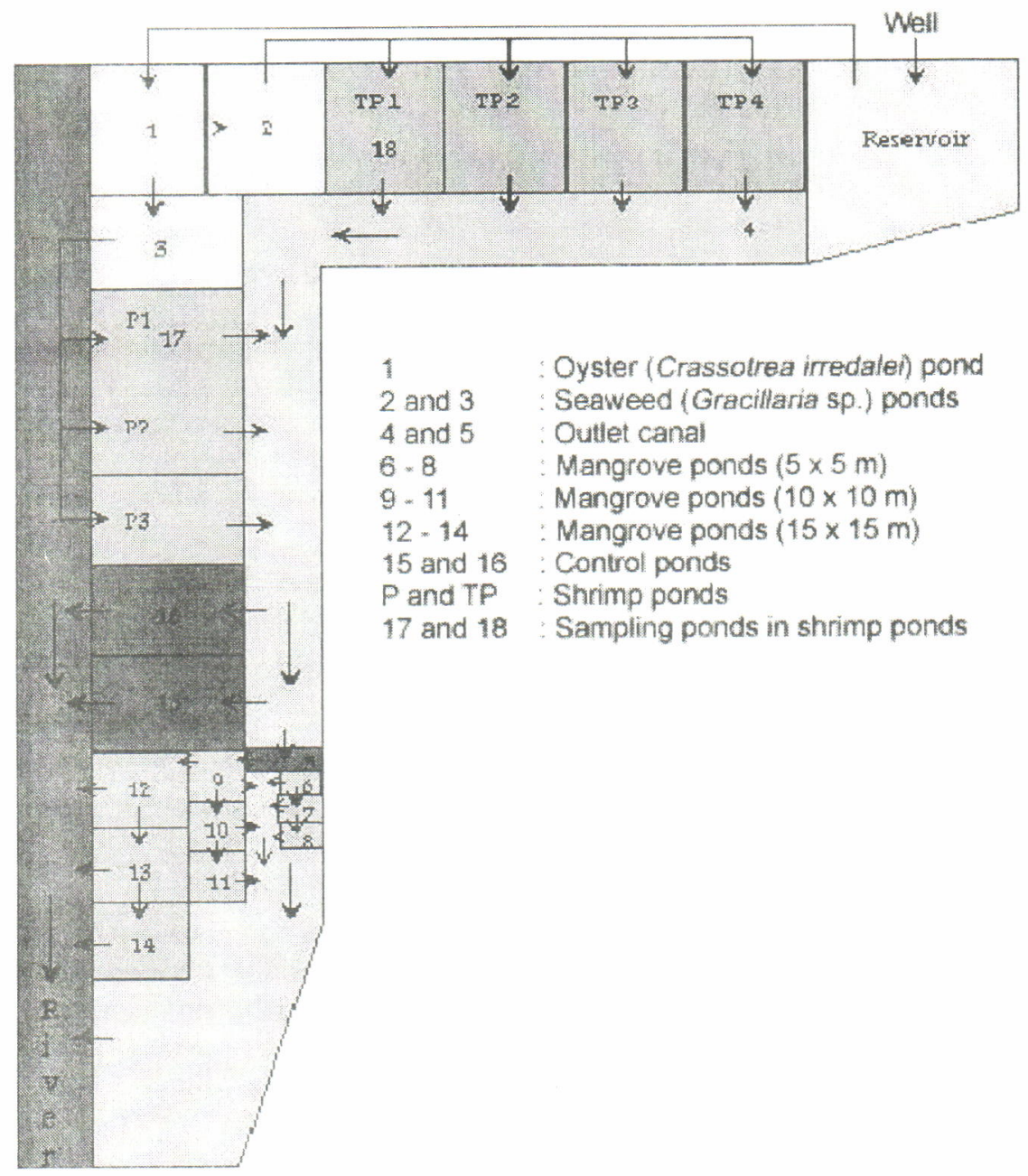

Figure 1. Experiment pond arrangement based on treatments 
The reservoir (1, 2, 3 in Figure) was a $1,500 \mathrm{~m}^{2}$ pond planted with sea weed (Gracillaria verrucosa) on the bottom and oyster (Crassostrea iredalei) at 28 individuals $/ \mathrm{m}^{2}$ set $10 \mathrm{~cm}$ above the bottom. The water in the reservoir was pumped out from a deep well and held three days before being allowed to flow into the shrimp ponds (Atmomarsono et al., 1995). Water and soil from both shrimp ponds (the same two ponds only) and reservoir were also sampled for $\mathrm{NO}_{3}-\mathrm{N}, \mathrm{PO}_{4}^{-}$ $P$, TOM concentrations and total bacteria population every 15 days. Each shrimp pond sample is expected to represent a row of ponds which is assumed to be homogenous based on the soil quality.

Both $\mathrm{NO}_{3}-\mathrm{N}$ and $\mathrm{PO}_{4}-\mathrm{P}$ of water and bottom soil were analysed using spectrophotometer with brucine sulphate and sodium tartrate methods, respectively (Haryadi et al., 1992). TOM in water was analyzed using a permanganate titrimetric method and in soil as loss on ignition (Melville, 1993). Total bacteria numbers were estimated from colony counts an TCBSA (Thiosulfate Citrate Bile Sucrose Agar). The data of each variable were plotted to produce a linear regression, and the slopes of the regression lines among

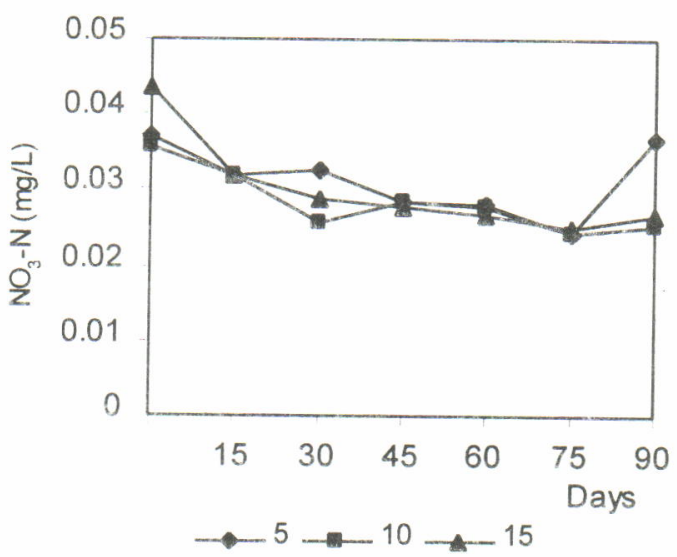

mangrove pond sizes were tested in an analysis of variance.

\section{RESULTS AND DISCUSSION}

In the mangrove ponds, all variables observed fluctuated with a tendency to slightly decrease. By the end of the experiment, $\mathrm{NO}_{3}-\mathrm{N}$ concentrations in the water of all ponds, except the $5 \times 5 \mathrm{~m}^{2}$ ponds, were slightly lower than in the initial concentrations. In the bottom soil, the concentrations of $\mathrm{NO}_{3}-\mathrm{N}$ were also decreasing and the concentrations in $5 \times 5 \mathrm{~m}^{2}$ ponds were slightly higher than in the rest of the ponds (Figure 2). Statistically, the decreasing rate of $\mathrm{NO}_{3}-\mathrm{N}$ concentrations as well as the initial concentrations were not significantly different $(P<0.05)$ among pond sizes

The concentrations of $\mathrm{PO}_{4}-\mathrm{P}$ in water decreased in the first 30 days, but then from day 30 started to fluctuate with a tendency of increasing to the end of the experiment. In the bottom soil, $\mathrm{PO}_{4}-\mathrm{P}$ concentrations started to increase 15 days earlier than in water. However from day 45 the concentrations kept decreasing until the end of the experiment (Figure 3 ).

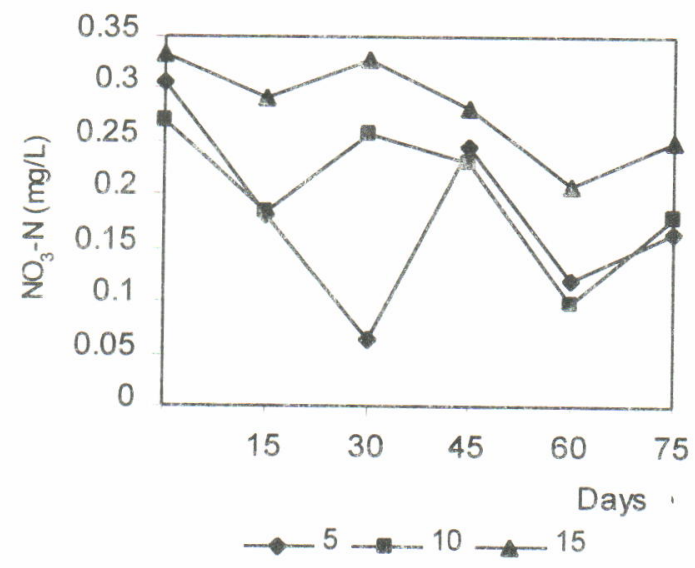

Figure 2. Concentration changes of $\mathrm{NO}_{3}-\mathrm{N}$ in water (left) and soil (right) of different sizes of mangrove pond
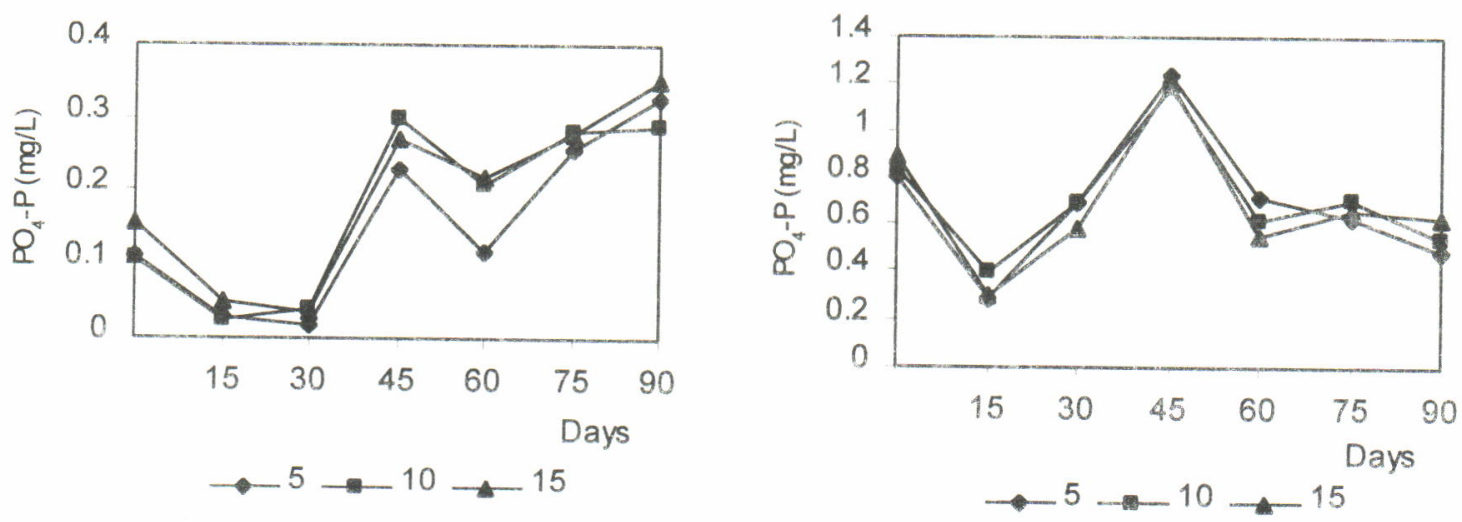

Figure 3. $\quad \mathrm{PO}_{4}-\mathrm{P}$ concentration changes in water (left) and soil (right) of different sizes of mangrove ponds 
In the settlement or control ponds and in the shrimp ponds, the behaviour of $\mathrm{NO}_{3}-\mathrm{N}, \mathrm{PO}_{4}-\mathrm{P}$, and TOM concentrations as well as total bacteria population was similar with that in mangrove ponds. In the case of total bacteria in water and soil, the population was not different among ponds except at the last sampling (Figure 6). In shrimp ponds, the bacteria population in water kept increasing while in mangrove and control ponds, it dropped on day 75. In the bottom soil, the bacteria population started to increase 15 days earlier than in water.

Figure 7 shows the changes of TOM concentrations in mangrove, shrimp, and control ponds. The concentrations in the water of all ponds increased in the first 60 days and after that distinctly decreased. In the bottom soil, TOM concentration seems to be more stable than in water.

In shrimp ponds, the concentration of $\mathrm{NO}_{3}-\mathrm{N}$ behaved as in both mangrove and control ponds. From
No differences were observed in the concentrations of $\mathrm{PO}_{4}-\mathrm{P}$ both in water and soil among pond sizes.

Total organic matter (TOM) concentration in water fluctuated very much, increasing in the first 45 and 60 days and then decreasing until the experiment terminated. On the other hand, TOM tended to be more stable in the bottom soil (Figure 4). The highest concentration in water, $100 \mathrm{ppm}$, was obtained at day 60 in $5 \times 5 \mathrm{~m}^{2}$ ponds, a day after heavy rainfall. On the same day, TOM concentration was the highest in the bottom soil of all ponds.

Surprisingly, high TOM content was only followed by an increase of total bacteria population in water but not in soil. The bacteria population in water started to increase on day 45 and exceeded $1.5 \times 10^{3} \mathrm{CFU} /$ $\mathrm{mL}$ at day 75 in $5 \times 5 \mathrm{~m}^{2}$ ponds (Figure 5 ). In soil, the bacteria population started to increase at day 60 and reached $30 \times 10^{3} \mathrm{CFU} / \mathrm{mL}$ in $10 \times 10 \mathrm{~m}^{2}$ ponds.
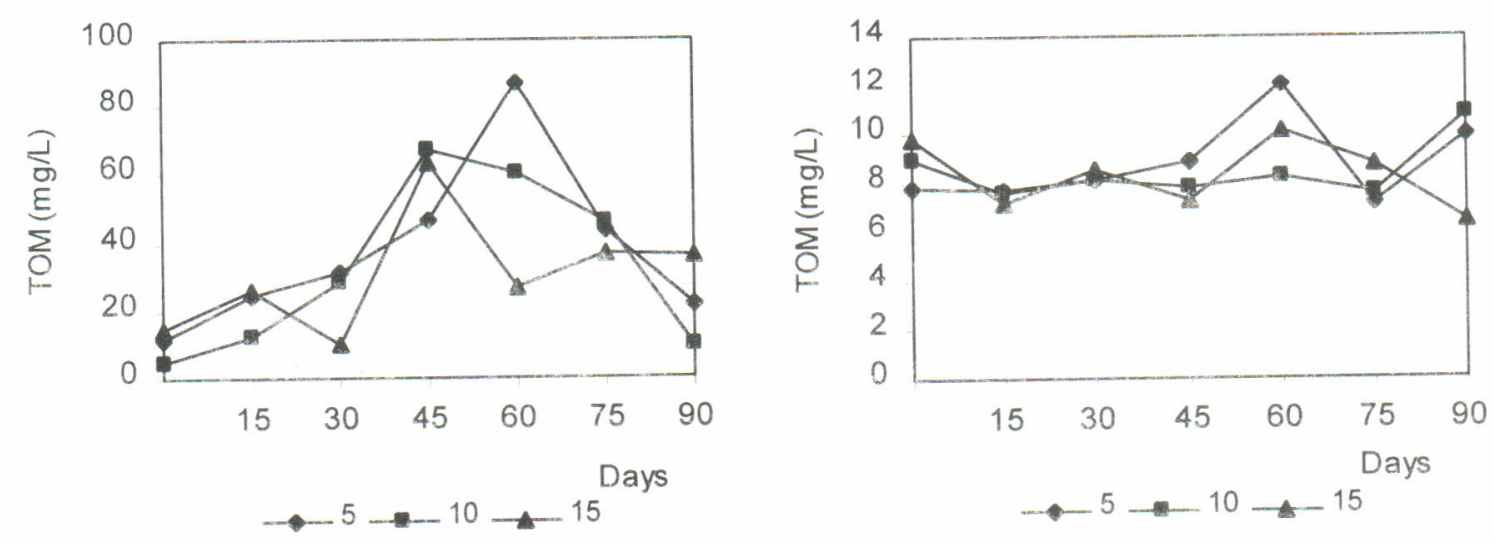

Figure 4. Concentrations of total organic matter in water (left) and soil (right) of different sizes of mangrove ponds
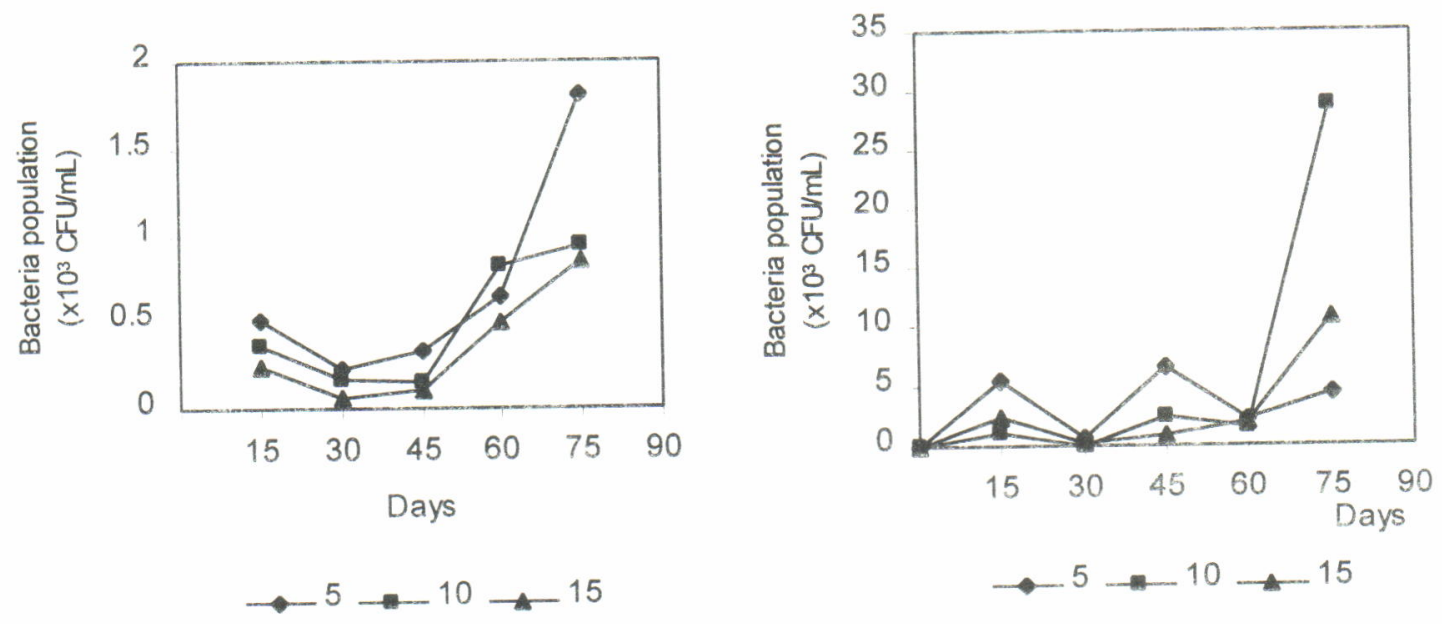

Figure 5. Total bacteria populations $\left(10^{3}\right)$ in water (left) and bottom soil (right) of different sizes of mangrove ponds 
the $45^{\text {th }}$ day after the PL were stocked, $\mathrm{NO}_{3}-\mathrm{N}$ increased but then declined in the last 15 days of the experiment. The addition of feed seemed to temporarily affect the concentration of $\mathrm{NO}_{3}-\mathrm{N}$ in shrimp and control ponds only (Figure 8 ). In the bottom soil, $\mathrm{NO}_{3}$ $\mathrm{N}$ concentrations declined in an almost similar pattern in all ponds. In fact, pond soil acts as a buffer which stabilize environmental conditions (Boyd and Massaut, 1998).

The inputs, more specifically feed, added to the shrimp pond started to affect $\mathrm{PO}_{4}-\mathrm{P}$ concentration in mangrove ponds water 15 days earlier than in shrimp and control ponds. The highest concentration of $\mathrm{PO}_{4}^{-}$ $P$ was observed in shrimp pond water at day 45 after the shrimps were stocked (Figure 9). A dense growth of diatomae in shrimp ponds, indicated by water colour which turned greenish brown, seemed to start absorbing $\mathrm{PO}_{4}-\mathrm{P}$ by day 45 causing the concentration of $\mathrm{PO}_{4}-\mathrm{P}$ to decline. In mangrove ponds, $\mathrm{PO}_{4}-\mathrm{P}$ uptake by mangrove vegetation and the associated organisms (Boyd, 1999; Robertson and Phillips, 1995) seems to stabilize $\mathrm{PO}_{4}-\mathrm{P}$ concentration in water 45 days after the shrimps were stocked.

The reduction of $\mathrm{NO}_{3}-\mathrm{N}$ concentration in water tended to be higher in mangrove ponds than in either control or shrimp ponds (Table 1). Mangrove vegetation, plankton and other organisms associated with the mangrove ecosystem (Table 2) seemed to be the main users of $\mathrm{NO}_{3}-\mathrm{N}$. In shrimp ponds, the addition of feed at $1.5 \mathrm{~kg} / 500 \mathrm{~m}^{2}$ produced less $\mathrm{NO}_{3}-\mathrm{N}$ than the
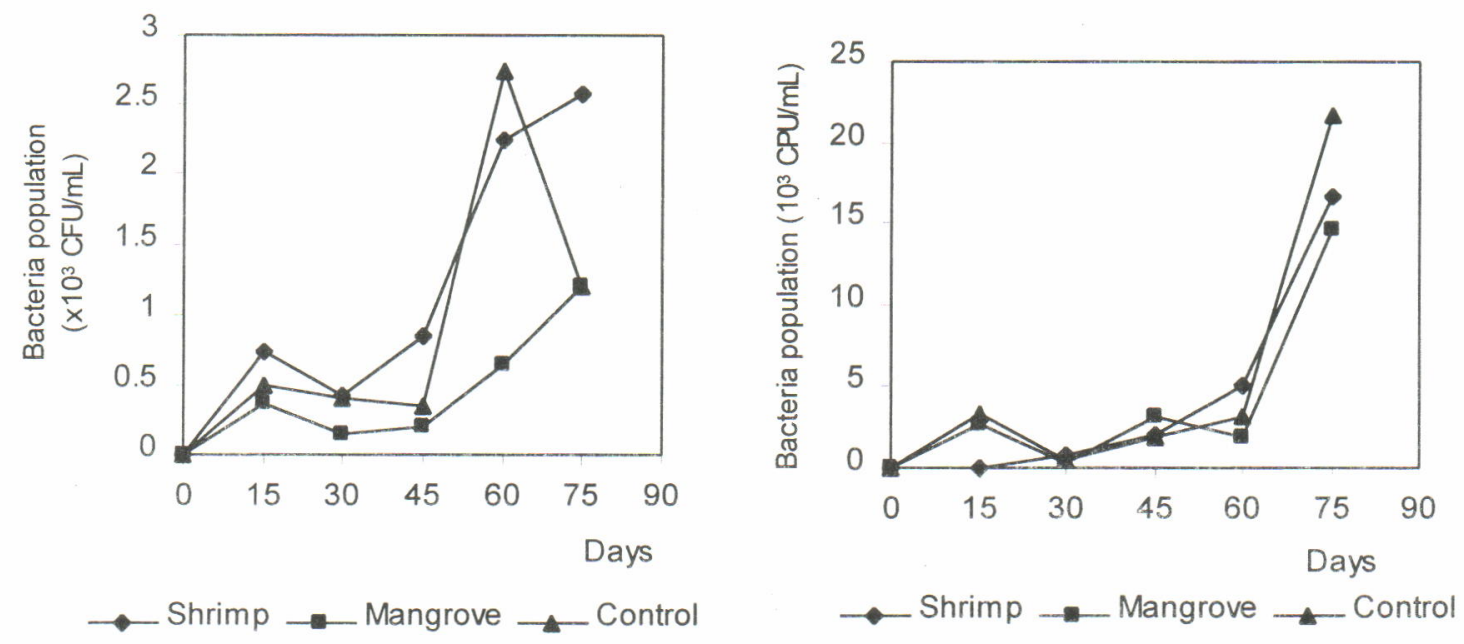

Figure 6. Average population of bacteria in water (left) and soil (right) of shrimp, mangrove and control ponds
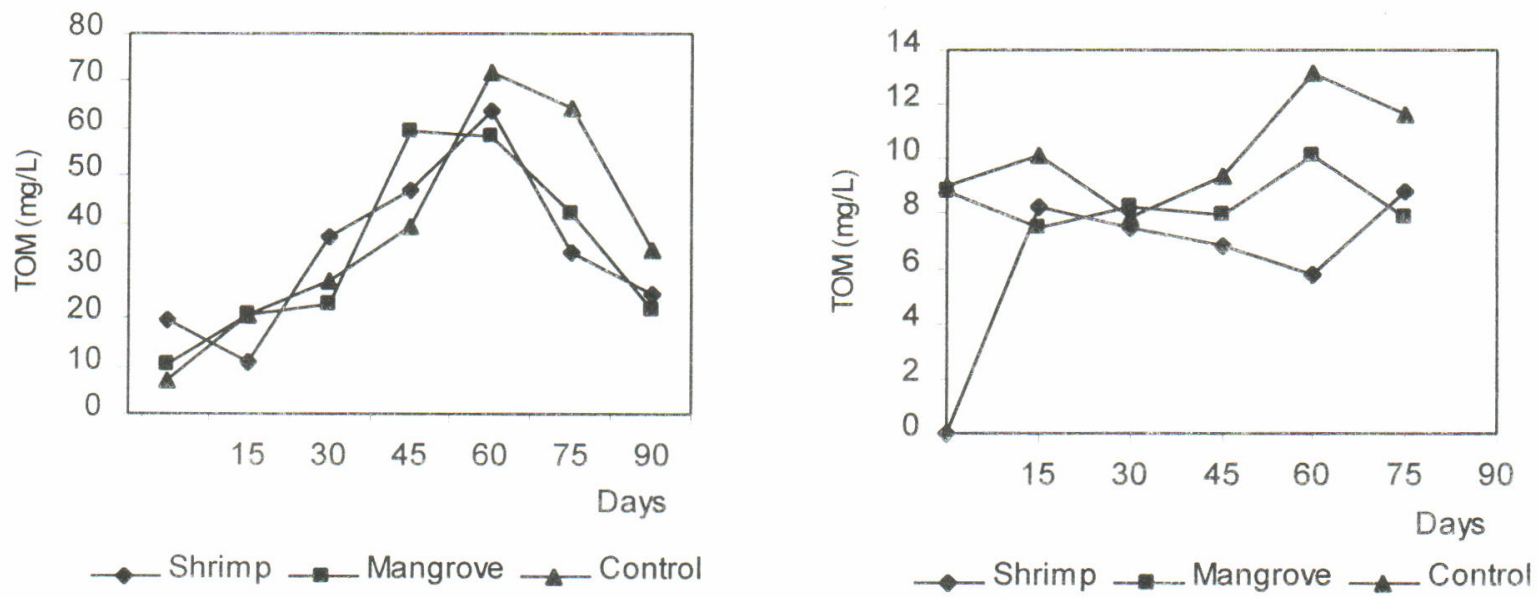

Figure 7. TOM concentrations in water (left) and soil (right) of shrimp, mangrove and control ponds 

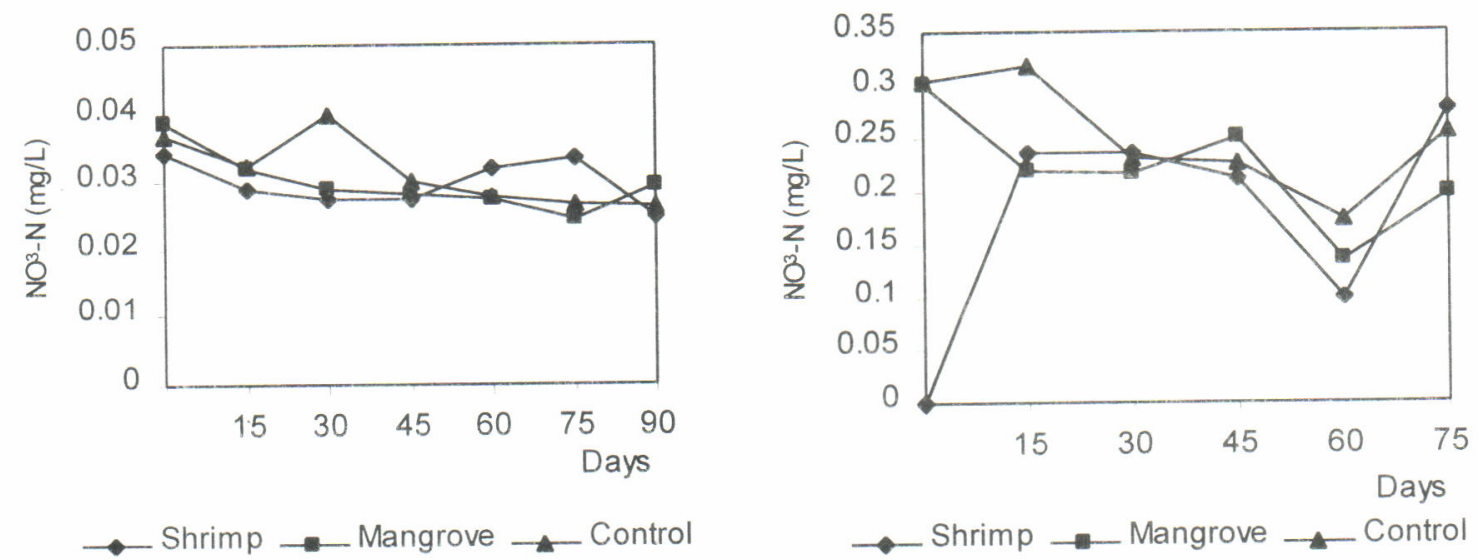

Figure 8. $\quad \mathrm{NO}_{3}-\mathrm{N}$ concentrations in water (left) and soil (right) of shrimp, mangrove, and control ponds
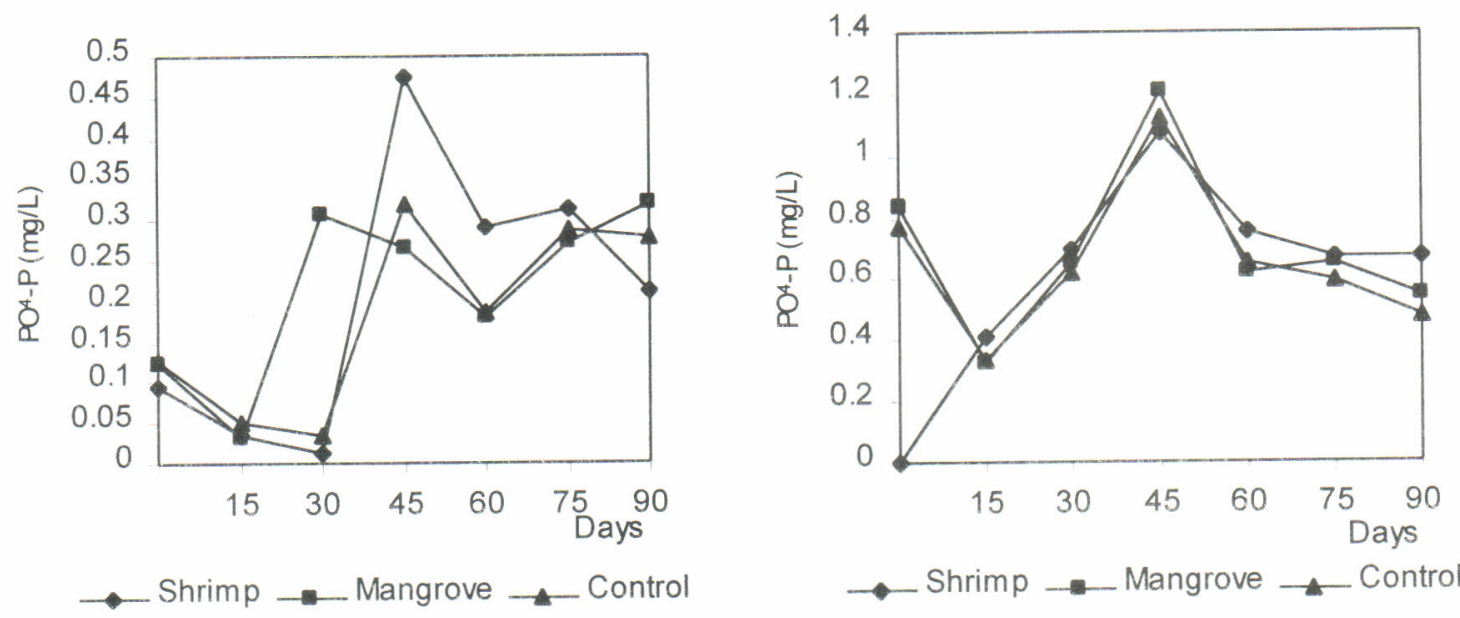

Figure 9. $\quad \mathrm{PO}_{4}-\mathrm{P}$ concentrations in water (left) and soil (right) of shrimp, mangrove and control ponds

amount used by phytoplankton (Figure 10). Nitrification seems to occur intensively due to the thorough dissolved oxygen distribution in the water column reaching the pond bottom. The light brown color of pond bottom soil indicated no anaerobic condition in the pond (Boyd et al., 1994).

The concentration of $\mathrm{PO}_{4}-\mathrm{P}$ slightly increased in mangrove, shrimp and control ponds. Based on the $r$ values in a linear regression, the change of $\mathrm{PO}_{4}-\mathrm{P}$ was more predictable than $\mathrm{NO}_{3}-\mathrm{N}$ concentrations. Even though the concentration of $\mathrm{PO}_{4}-\mathrm{P}$ was high compared to natural water (Boyd, 1979), the ratio of $\mathrm{NO}_{3}-\mathrm{N}$ to $\mathrm{PO}_{4}-\mathrm{P}$ was below that which would encourage eutrophication due to $\mathrm{NO}_{3}-\mathrm{N}$ limitation. Bloom of plankton as a result of eutrophication usually occurs at a N-P ratio more than 10 (Ahmad et al., 1998).

The addition of inputs in terms of artificial feed increased the concentration of $\mathrm{PO}_{4}-\mathrm{P}$ in shrimp pond water up to $0.47 \mathrm{mg} / \mathrm{l}$ by day 45 . Then, the concentration started to decrease and reached $0.22 \mathrm{mg} / \mathrm{l}$ by day 90 . The changes in feed input, $10 \%$ of total biomass in the first month, $5 \%$ in the second month, and $3 \%$ in the third month are suspected to be the main cause. In the first month, the shrimp were so small that not all the feed was consumed. Consequently, in the first 45 days, most of the feed decomposed into inorganic compounds such as phosphate, nitrate, and ammonia as well as unionized ammonia which then flowed into both control and mangrove ponds. In the second and third months, the shrimp were better able to take and consume the feed, which reduced the amount of unconsumed feed. Boyd (1979) and Poernomo (1988) reported that one of the main sources of phosphate in shrimp ponds is artificial feed.

The changes of TOM in a linear regression were more unpredictable, especially in the control pond, 
Table 1. Regression values of various water quality variables in shrimp, mangrove and control ponds

\begin{tabular}{llccc}
\hline \multirow{2}{*}{ Variable } & Pond & \multicolumn{3}{c}{ Regression parameters } \\
\cline { 3 - 5 } & & $\mathbf{a}$ & $\mathbf{b}$ & $\mathbf{r}$ \\
\hline NO3-N (mg/L) & Shrimp & 0.0314 & -0.00000 & -0.3141 \\
& Mangrove & 0.0694 & -0.00006 & -0.4925 \\
& Control & 0.0368 & -0.00001 & -0.6928 \\
PO4-P (mg/L) & Shrimp & 0.0763 & 0.00028 & 0.5444 \\
& Mangrove & 0.042 & 0.00029 & 0.8067 \\
& Control & 0.066 & 0.00026 & 0.7199 \\
TOM (mg/L) & Shrimp & 24.0712 & 0.2139 & 0.388 \\
& Mangrove & 21.4716 & 0.26886 & 0.4434 \\
& Control & 16.6623 & 0.49383 & 0.6933 \\
Bacteria (10 & & & & \\
& Shrimp & 0.3756 & 0.0161 & 0.7185 \\
CFU/mL) & Mangrove & -0.054 & 0.0115 & 0.7915 \\
& Control & -0.007 & 0.0237 & 0.562 \\
\hline
\end{tabular}

Table 2. Macro benthos and plankton qualitatively identified in the experiment ponds

\begin{tabular}{|c|c|c|}
\hline Pond & Benthos & Plankton \\
\hline Mangrove & $\begin{array}{l}\text { Cerithidea, Littorina, } \\
\text { Tellina, Crassostrea, } \\
\text { Neritopsis }\end{array}$ & $\begin{array}{l}\text { Amphora, Oscillatoria, Nitzschia, Acartia, } \\
\text { Brachionus, Pleurosigma, Biddulphia, Anabaena, } \\
\text { Surirellea, Calotrix }\end{array}$ \\
\hline Shrimp & Cerithidea, Littorina & $\begin{array}{l}\text { Brachionus, Oscillatoria, Acartia, Pleurosigma, } \\
\text { Anabaena, Nitzschia, Amphora, Surirellea, } \\
\text { Chaetoceros, Biddulphia }\end{array}$ \\
\hline Control & Cerithidea, Littorina & $\begin{array}{l}\text { Oscillatoria, Brachionus, Acartia, Nitzschia, } \\
\text { Amphora, Pleurosigma, Surirellea }\end{array}$ \\
\hline
\end{tabular}

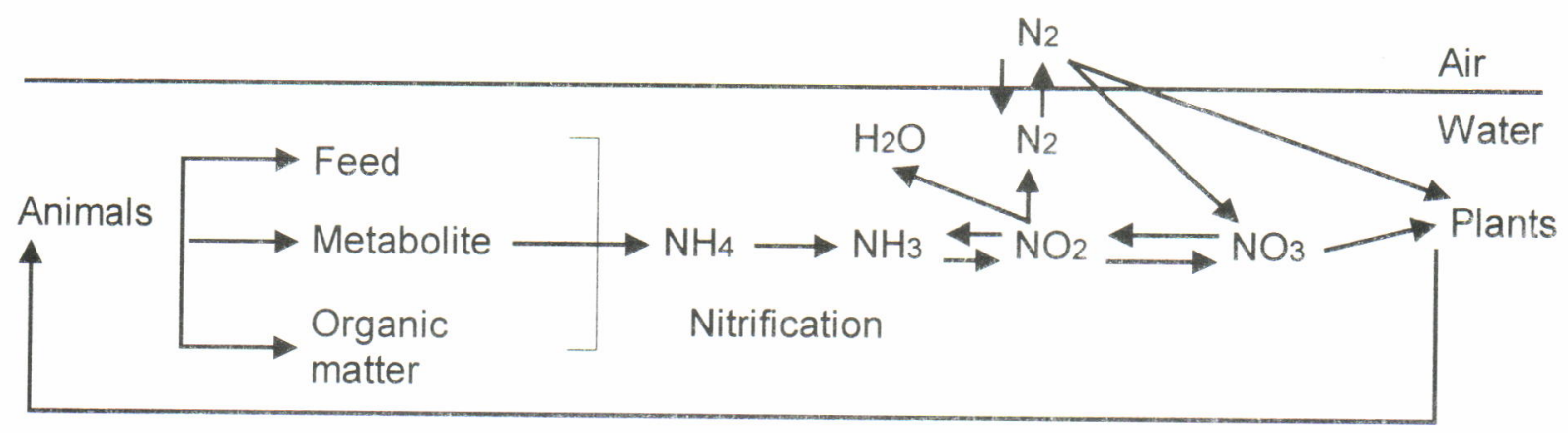

Figure 10. The cycle of nitrogen in ponds (after Boyd, 1991)

compared to those of $\mathrm{PO}_{4}-\mathrm{P}$ concentration. It seems that more organic matter accumulated in control pond than in both mangrove and shrimp ponds. The increase in TOM concentration followed by the increase of bacteria population was more observable in shrimp ponds than in control and mangrove ponds. Sedimentation in three days without addition of input and also tannin contained in mangrove litter were suspected to inhibit the growth of bacteria in water (Atmomarsono et al., 1995; Harahap, 1997). 
The behavior of $\mathrm{NO}_{3}-\mathrm{N}, \mathrm{PO}_{4}-\mathrm{P}$, and TOM concentrations and bacteria populations in pond bottom soil was more or less similar with those in water even though the changes were more unpredictable, except for the bacteria population (Table 3). Ahmad (1998) observed similar patterns of $\mathrm{NO}_{3}-\mathrm{N}$ and $\mathrm{PO}_{4}-\mathrm{P}$ changes in mangrove stands for almost two years. In shrimp pond bottom soil, the growth of the bacteria population was more than twice that in mangrove pond bottom soil. The litter (leaves and branches) of mangrove containing tannin (Soetarno, 1997) is suspected to inhibit the growth of bacteria populations (Table 4 ) in both water or pond bottoms.
Based on the findings above, mangrove stands have potential for shrimp ponds waste-water treatment. Further, they could be used in an ecofriendly recirculating shrimp culture system. Ahmad (1988), reported that the maximum area of mangrove forest which could be converted into productive shrimp ponds is less than $20 \%$ of the total area based on salinity distribution, amplitude of tide, soil quality and texture, as well as land elevation, However, more in-depth study on the organisms associated with the mangrove ecosystem or the active substances contained in mangrove trees should be carried out to assure the optimal use of mangrove stands in shrimp culture.

Table 3. The regression values of various variables in shrimp, mangrove, and control ponds soil

\begin{tabular}{llccc}
\hline \multirow{2}{*}{ Variable } & Pond & \multicolumn{3}{c}{ Regression parameters } \\
\cline { 3 - 5 } & & $\mathbf{a}$ & $\mathbf{b}$ & $\mathbf{r}$ \\
\hline NO3-N (mg/L) & Shrimp & 0.2291 & -0.00004 & -0.1318 \\
& Mangrove & 0.2735 & -0.00014 & -0.7061 \\
& Control & 0.2568 & -0.00012 & -0.6282 \\
PO4-P (mg/L) & Shrimp & 0.5545 & -0.00011 & -0.1208 \\
& Mangrove & 0.6771 & -0.00011 & -0.1018 \\
& Control & 0.6411 & 0.00037 & 0.3741 \\
TOM $(\mathrm{mg} / \mathrm{L})$ & Shrimp & 7.604 & -0.0043 & 0.0851 \\
& Mangrove & 8.2088 & 0.5238 & 0.1529 \\
& Control & 8.6772 & 0.00047 & 0.14038 \\
Bacteria $(1000 \mathrm{CFU} / \mathrm{mL})$ & Shrimp & -6.358 & 0.2501 & 0.8718 \\
& Mangrove & -3.042 & 0.1683 & 0.6984 \\
& Control & -5.652 & 0.2613 & 0.7072 \\
\hline
\end{tabular}

Table 4. Vibrios identified in the experiment ponds

\begin{tabular}{lll}
\hline Ponds & \multicolumn{1}{c}{ Water } & \multicolumn{1}{c}{ Soil } \\
\hline \multirow{2}{*}{ Mangrove } & Vibrio campbellii, V. leiognathi, & Vibrio metschnikovi, V. harveyii, \\
& V. splendidus, V. harveyii, V. cholerae, & V. mimicus, V. cholerae, V. alginolitycus, \\
& V. tubiashi, V. metschnikovi, V. & V. campbellii, V. tubiashi, \\
& cholerae, V. ordalli, V. alginoliticus, & V. parahaemoliticus, P. anguillarum, \\
& V. harveyii, V. natriegens & V. natriegens, V. splendidus, V. fischeri \\
Shrimp & Vibrio mimicus, V. alginolitycus, & V. mimicus, V. cholerae, metschnikovi, \\
& V. cholerae, V. splendidus, & V. splendidus \\
& V. metschnikovi, V. fischeri & \\
Control & V. mimicus, V. tubiashi, V. campbelli, & V. mimicus, V. cholerae, V. leiognathi, \\
& V. alginolitycus, V. fischeri, & V. haneyii \\
& V. leiognathi, V. cholerae, V. ordalli, &
\end{tabular}




\section{CONCLUSIONS}

The use of mangroves for shrimp ponds wastewater treatment is promising for reducing the possibility of eutrophication, which is usually followed by disease out-breaks caused by organic pollution generated in shrimp ponds. Further in-depth study on the organisms associated with the mangrove ecosystem for shrimp ponds bioremediation is recommended.

\section{ACKNOWLEDGEMENTS}

The research was funded by the Government of Indonesia through the Agricultural Development Project FY 1999/2000. Three submersible pumps and a water quality checker were provided by Japan International Research Center for Agricultural Sciences through a collaboration project on nutrient cycling in the coastal area of Indonesia. The hard work of researchers, technicians, and a typist in supporting the research and preparing the manuscript is highly appreciated.

\section{REFERENCES}

Ahmad, T. 1988. Potentialities of mangrove forest related to coastal aquaculture: a case study in BoneBone. Luwuk, South Sulawesi. Mangrove Management: Its ecological and economic considerations. Biotrop Special Publication (37): 217-299

Ahmad, T. 1998. Natural improvement of brackishwater ponds productivity. Seminar on Indonesia Marine Biotechnology I, 14-15 October 1998. LIPI, Jakarta: 8598.

Ahmad, T., M.J.R. Yakob, and E. Ratnawati. 1998. Milkfish intensive culture. First Edition. Penebar Swadaya, Jakarta. $96 \mathrm{pp}$

Atmawidjaja, R. 1987. Conservation in the framework of mangrove forest utilization in Indonesia. Proceeding of Seminar III, Mangrove Ecosystem. Indonesian Board of Science-Ministry of Forestry, Jakarta: 63-73.

Atmomarsono, M., Muliani, and S. Ismawati. 1995. The prospects on reservoir in shrimp culture. Technology Package Application, Station for Research and Assesment Agricultural Technology, Wonocolo, Surabaya, Indonesia, 2-4 July 1995. 10 pp.

Boyd, C.E. 1999. Codes of practice for responsible shrimp farming. Global Aquaculture Alliance, St. Louis, MO. USA. 48 pp.

Boyd, C.E. 1991. Water quality management and aeration in shrimp farming. Technical Guidance, Fisheries Research and Development Project. Centre Research Institute for Fisheries. Jakarta. 82 pp.

Boyd, C.E. and L. Massaut, 1998. Soil in pond aquaculture. Aquaculture Asia. III(1): 6-10.

Boyd, C.E. 1979. Water quality in ponds for aquaculture. Craftmaster Printers, Inc. Opelika Alabama, USA. 365 pp.

Boyd, C.E., P. Munsiri, and B.F. Hajek. 1994. Composition of sediment from intensive shrimp ponds in Thailand. World Aquaculture. 25: 53-55
Harahap, F. 1997. Chemical analysis in n-hexane and benzene fraction of mangrove, Rhizophora mucronata Lamk, bark. Master of Science Thesis. Hasanuddin University, Ujung Pandang, Indonesia. 68 pp.

Haryadi, S., I.N.M. Suryadiputra, and B. Widigdo, 1992 Practical quidence on water quality analysis. Faculty of Fisheries, Bogor Agricultural university, Indonesia $55 \mathrm{pp}$.

Kartawinata, K.S., S. Adisoemarto, S. Soemadihardjo, and I.G.M. Tantra. 1978. The status of the knowledge on mangrove forest in Indonesia In Soemodiharjo, S., A. Nontji, and A. Jamali. Proceedings of the Seminar on Mangrove Forest Ecosystem, Jakarta 27 February-1 March 1978. MAB Indonesia and LIPI. Jakarta. p. 21-40.

Mangampa,M., M. Tjaronge, and S. Tahe. 1998. The effect of depth arrangement of oyster (Crassostrea irredalel) as biofilter in intensive shrimp pond reservoir. Research Report, Research Institute for Coastal Fisheries, Fy 1999/2000. 9 pp.

Massaut, L. 1998. Mangrove management and shrimp aquaculture. Department of Fisheries and Allied Aquaculture, and International Center for Aquaculture and Aquatic Environments, Auburn University, Al.

Melville, M.D. 1993. Soil laboratory manual. School of Geography. University of New South Wales, Australia. $74 \mathrm{pp}$.

Notohadiprawiro, T. 1978. Edaphological characteristics of mangrove soil. In Soemodiharjo, S., A. Nontji, and A. Jamali. Proceedings of the Seminar on Mangrove Forest Ecosystem, Jakarta 27 February-1 March 1978. MAB Indonesia, LIPI, Jakarta. 40-54.

Nontji, A. 1984. Nusantara Sea. UI Press Publisher. Jakarta. 105-113

Poernomo, A. 1988. Shrimp pond construction in Indonesia. Agency for Agricultural Research and Development, Ministry of Agriculture. Development Series No.7: $29 \mathrm{pp}$.

Robertson, A.I., and M.J. Phillips. 1995. Mangrove as filters of shrimp pond effluent: Practions and biogeochemical research needs. Hydrobiology. 295: 311-321.

Soemodihardjo and Soeroyo. 1992. The impact of marine pollution on mangrove community. Proceedings of the Seminar on Marine Pollution Monitoring. Center for Oceanological Research and Development, LIPI, Jakarta. $175 \mathrm{pp}$.

Soetarno, S. 1997. The potentiality and advantage of mangrove plants as sources of bioactives. Acta Pharmaceutica Indonesia. Vol.XXII, No. 4: 84-103

Suharyanto,M., M. Atmomarsono and A. Sudradjat, 1996. The use of 3 species of bivalves as biofilter in shrimp culture. Indonesian Fisheries Research Journal, II(1): 31-38.

Tjaronge, M.,Mangampa, and Burhanuddin, 1998. The effect of different mangrove clam, Geloina coaxan, arrangement as biofilter on intensive shrimp ponds. Research Report, Research Institute for Coastal Fisheries, FY 1997/1998. 9 pp. 